\title{
EVALUATION OF IMPACT OF SOIL COMPACTION IN DITCH-SIDES DURING FORWARDING OF ROUNDWOOD ON GROUNDWATER LEVEL IN NEIGHBOURING FOREST STAND
}

\author{
Janis Ivanovs, Raitis Melniks, Ilona Skranda \\ Latvian State Forest Research Institute "Silava", Latvia \\ janis.ivanovs@silava.lv, raitis.melniks@silava.lv, ilona.skranda@silava.lv
}

\begin{abstract}
The aim of the study is to evaluate the impact of forest machines on soil compaction in ditch-sides and to describe the impact of soil compaction on water exchange between forest stands and drainage ditches. The study was carried out in Ceraukste parish. Three research objects have been selected nearby the newly constructed forest roads, where timber delivery has not yet been carried out. Each research object includes an experimental plot and a control area, each covering a 50-meter long area along the road, including a ditch tip and a 15-meter-wide forest strip. Field works include collection of data on soil penetration resistance, groundwater level monitoring, and collection of soil samples for determination of water permeability rate. The study concludes that, as a result of forwarding, the soil layer at the depth of $20-60 \mathrm{~cm}$ is substantially compacted during forwarding and soil compaction has a negative effect on changes of the groundwater level in the forest stand bordering with the test objects. The study concludes that the number of samples to be tested for water permeability should be significantly increased in order to characterize the water filtration rate. The results of the water permeability rate analyses in 2017 and 2018 are contradictory. It is possible that the difference in the results is due to the fact that the backing is overlapping during the construction process and then, after aligning the ditch-side after the transfer, is mixed. Water filtration properties tend to recover over time, so it is useful to repeat observations on the backwaters after several years to assess how long the impact of the timber delivery on the soil remains, as well as to increase the diversity and intensity of measurements by putting new sample plots in areas with different soil texture.
\end{abstract}

Keywords: soil compaction, ruts, water table.

\section{Introduction}

In a study conducted in Germany [1] it was found that in the ruts made by logging machinery soil aeration in the depth of $12-24 \mathrm{~cm}$ was reduced for up to three years compared to unaffected soil. Infiltration capacity was reduced and penetration resistance was increased. Whereas in France [2], long term studies have recorded changes in the soil infiltration capacity and decrease in the soil pore size.

Soil compaction is one of the main risk factors affecting the soil quality and the European Union is paying more attention to issues related to it [3]. Aspiration for the highest productivity in forestry is leading to practice where logging is carried out throughout the year, regardless of the weather, wherever possible [4]. The logging machinery primarily changes the physical properties of soil by causing vibrations, pressure and shear, which lead to soil compaction and rutting. Soil compaction is one of the main reasons that contribute to reduction of soil porosity [5]. Soil compaction intensity is directly dependent on the soil type. The amount of soil macropores can decrease to as much as $60 \%$ and its bulk density can increase by $22-40 \%$. The most significant impact on loam and clay soils is on the first $30 \mathrm{~cm}$ of the soil [6], but loam and sand can be impacted even deeper than $70 \mathrm{~cm} \mathrm{[1].} \mathrm{Soil}$ compaction reduces exchange of water in the soil and limit aeration, which hinders development of roots and activity of microorganisms [7]. Compacted soil makes it difficult for tree roots to spread, reducing their ability to absorb water and nutrients [8]. These factors slow down the growth rate of trees and reduce the ability of plantations to survive [9]. The impact of these factors depends on the soil moisture regime and the type of forest growth conditions, as well as the dominant tree species [10]. These factors also influence changes in plant communities when different plant species suppress those that were forming habitats before [2;11].

The groundwater level determines physiological processes of plants and the exchange of elements in the tree root system. High groundwater level can cause tree roots to die [12]. Dying of pine and spruce roots begins when they are flooded for more than 3-5 days, but they regenerate in 2-4 weeks, depending on the degree of damage. For pine, this process is faster due to their better adaptation to wet conditions [13]. 
Soil moisture regime is an important parameter in soil compaction. In wet seasons, such as autumn and spring, the risk of compaction is higher. Impact on soil porosity by compaction is higher in clay and loam soils than in sandy soils [14].

Compaction affects water infiltration and movement not only in vertical, but also in horizontal direction. For example, ruts in clay soils impede the horizontal flow of groundwater by about $33 \%$. In cases where the logging path is planned perpendicular to the direction of the natural flow, depending on the soil granulometric composition, it may contribute to the paludification of the site [15].

\section{Materials and methods}

The study area is located in Ceraukste parish. The study plots are located near to newly constructed forest roads, where ditches were excavated and the extracted soil layer was left on the banks of the ditches, forming an elevated surface. The study area is shown in Fig. 1. There are 3 sampling plots and 3 control plots that together form 3 research objects.

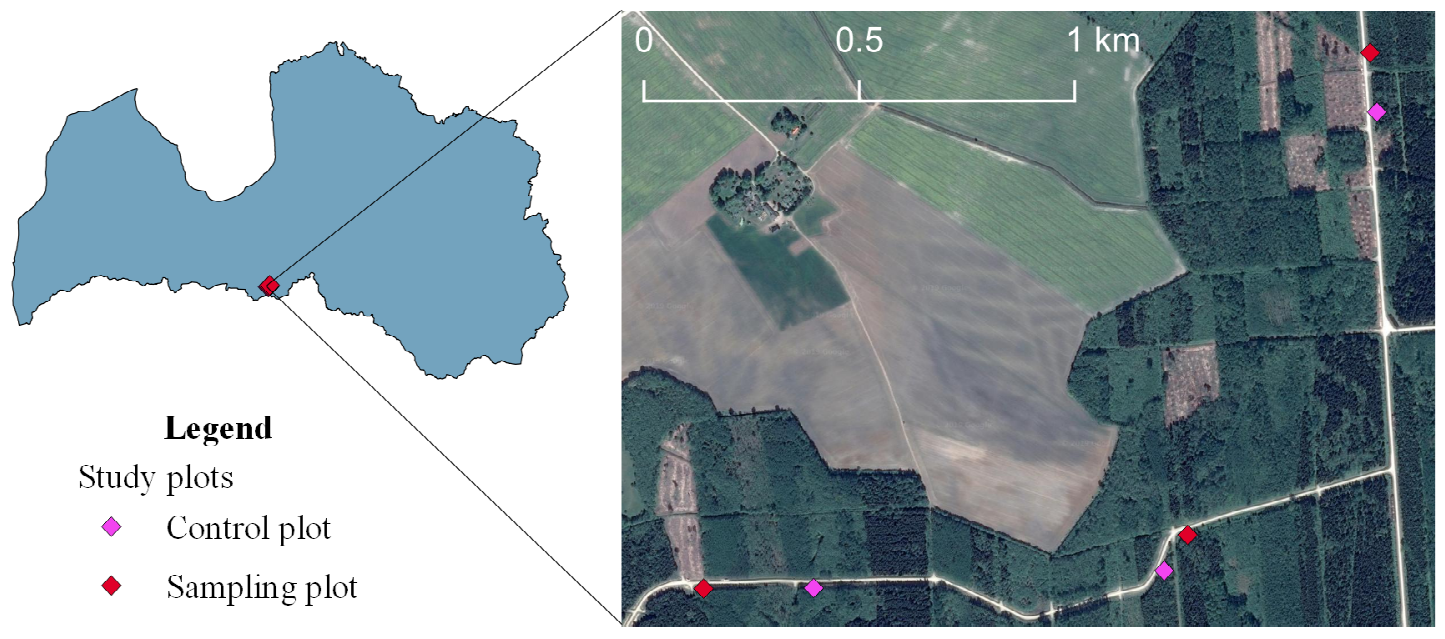

Fig. 1. Study area

Sample plots are located in areas where heavy logging equipment was moved on top of newly formed elevated ditch banks during logging in the autumn 2017. Control plots were located at least 50 $\mathrm{m}$ away from the sampling plots in morphologically similar areas. Similarity of the control plots and paired sampling plots is determined using a soil penetrologger. Plots with similar soil bearing capacity are considered as morphologically similar. An example of similarity of soil penetration resistance in different places is shown in Fig. 2.

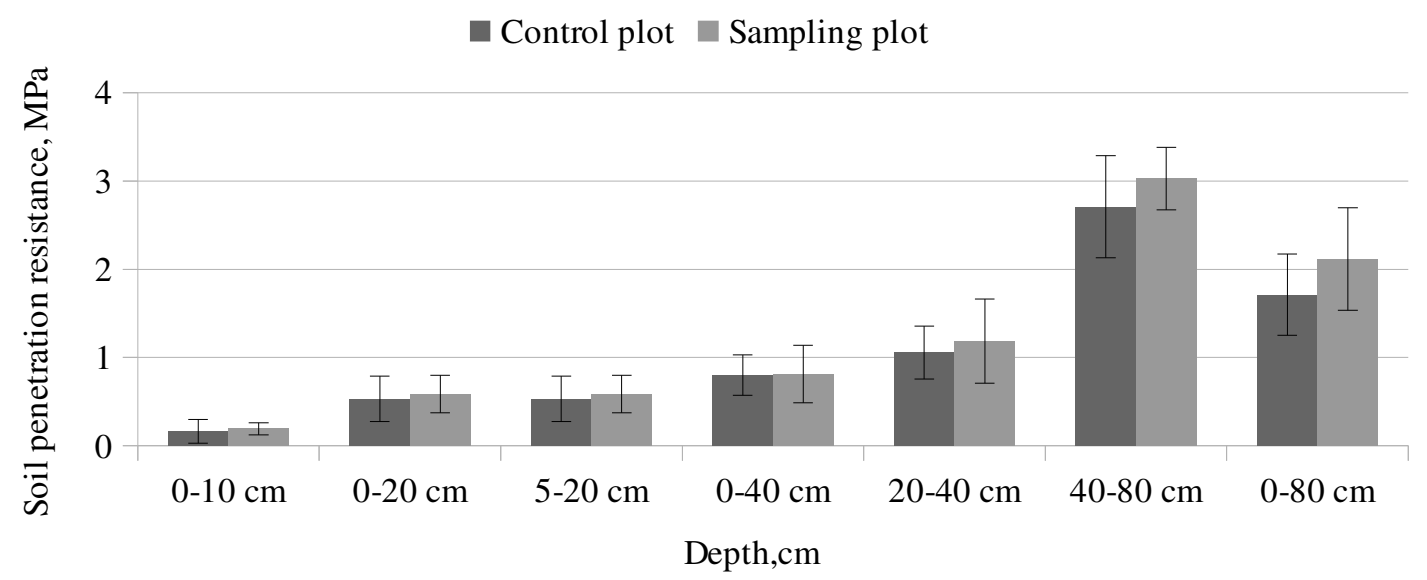

Fig. 2. Soil penetration resistance before compaction

During the logging period, the harvesting machinery moved only through the plots that were dedicated for timber stocking, while the control areas were not affected. The dominant type of quaternary sediments in the study area is silty clay [16]. 
Each study plot and the control plot cover an area of $750 \mathrm{~m}^{2}(15 * 50 \mathrm{~m})$, including a ditch bank and a $10 \mathrm{~m}$ wide adjacent area of the forest. Soil penetration resistance measurements were performed on both the plot and the control area in summer 2017 with the Eijkelkamp penetrologger. Soil moisture measurements were not made, however, meteorological observations at the nearby Bauska meteorological observation station show that 10 days prior to the measurements there were periodic precipitation and total rainfall of $34.5 \mathrm{~mm}$.

In the summer of 2017, groundwater monitoring wells were set up in the study plots and control areas. The wells are used to find out how the soil compaction caused by the logging machinery on the banks of ditches affects the flow of groundwater in the direction to the ditch. The water pressure in the groundwater wells was measured with the Vanessen instrument Mini-Diver. Air pressure was measured with Diver-DXT. Data reading was done with the Diver_Office software, which performed a pressure compensation procedure, which resulted in the height of the water column in the well. The diameter of the well is $75 \mathrm{~mm}$. Average well depth is $1.52 \mathrm{~m}$. Groundwater data are recorded at $1 \mathrm{~h}$ intervals.

In the summer of 2018, soil samples were collected at 4 different depths $(0-10 \mathrm{~cm}, 10-20 \mathrm{~cm}, 20$ $40 \mathrm{~cm}$ and $40-80 \mathrm{~cm}$ ) on the ditch banks and adjacent forests. The obtained soil samples were subjected to laboratory analysis, resulting in determination of the density of different soil layers (LVS ISO 11272: 1998), granulometric composition (LVS ISO 11277: 2000) (Laboratory of Silava) and water permeability (Laboratory of the Faculty of Geography and Earth Sciences, University of Latvia).

The results of the soil penetration resistance, granulometric composition, water permeability and groundwater level measurements from the control and study plots were compared. The results of the soil penetration resistance were analyzed by looking at different depths and different depth classes. Soil bearing capacity at the beginning and the end of the study is not directly compared, as measurements have been made under different soil moisture conditions. Precipitation and temperature data were taken from the website of the Latvian Environment, Geology and Meteorology Centre. Meteorological data were obtained at hourly intervals and the corresponding daily and average values were calculated. The filtration properties of the collected soil samples were determined by the Latvia University of Life Sciences and Technologies laboratory (LLU). Groundwater monitoring data were also analysed in cooperation with specialists from LLU.

\section{Results and discussion}

The results of analysis of the soil penetration resistance are summarized in the following diagrams. As shown in Fig. 3, the bearing capacity of the soil in the research object was similar in the initial state when comparing the sampling and control plots. The soil penetration resistance in the control area of the first study object increases evenly depending on the depth. At a depth of $80 \mathrm{~cm}$, the soil penetration resistance exceeds $4 \mathrm{MPa}$ in both the control and the sampling plot.

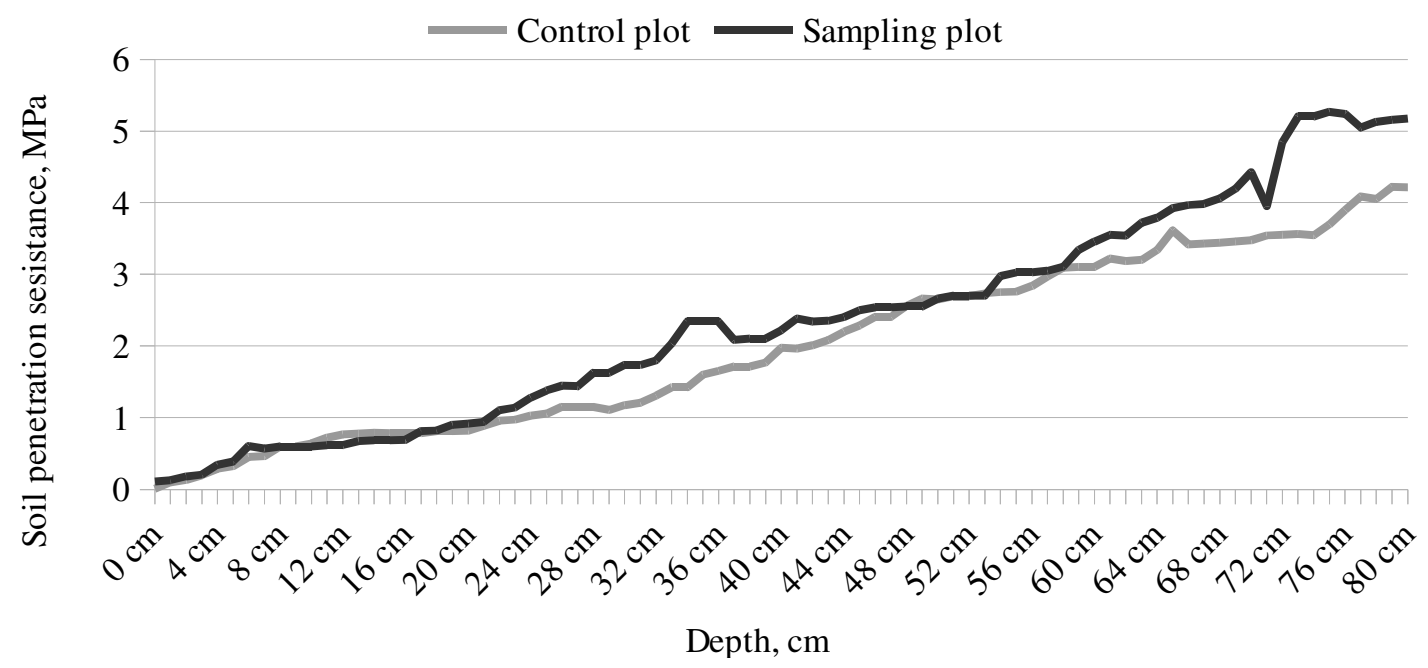

Fig. 3. Soil penetration resistance before compaction 
Repeated measurements of the soil penetration resistance were made after completion of the logging process and filling the ruts. The penetration resistance in sampling plots has increased significantly compared to the control area (Fig. 4). Comparing the results with those obtained previously, it can be seen that the overall resistance of soil penetration in this research object has decreased, probably due to higher soil moisture regime. However, the soil penetration resistance in the sampling plot is up to two times higher than in the control area. It should be noted that the depth of the ruts in the study plots was $20-30 \mathrm{~cm}$. Ruts were filled with loose soil, so the upper layer on ditch banks has not been subjected to compaction. Other research objects showed similar trends for the depth up to $60 \mathrm{~cm}$. From the results of the soil penetration resistance measurements it can be concluded that the greatest effect of soil compaction from logging is observed in the soil layer at a depth of 20-60 cm. This corresponds to the observations from [1], who noted that coil compaction on sand and loam soils can be impacted even deeper than $70 \mathrm{~cm}$.

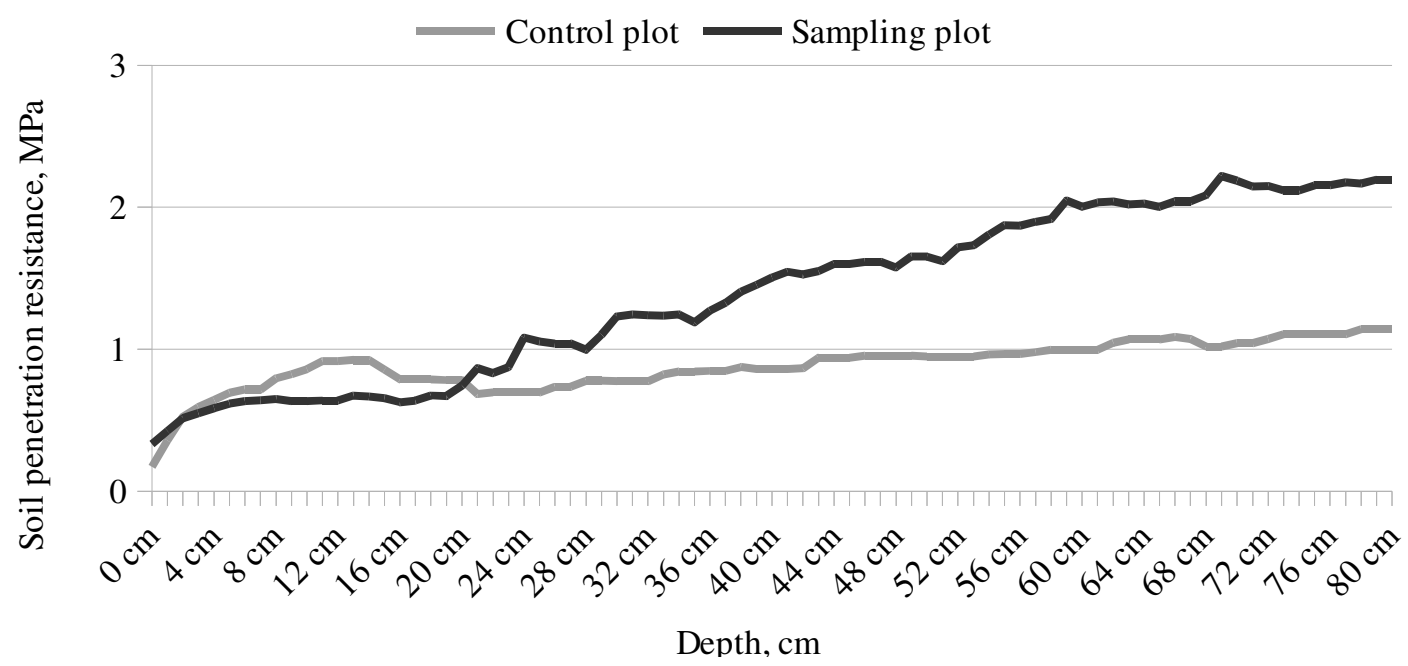

Fig. 4. Soil penetration resistance after compaction in sampling plot

Groundwater monitoring results from the study object 2 are shown in Fig. 5. They include measurements from the control areas and sampling plots, as well as 24-hour rainfall and average air temperature data from the nearby Bauska meteorological observation station.

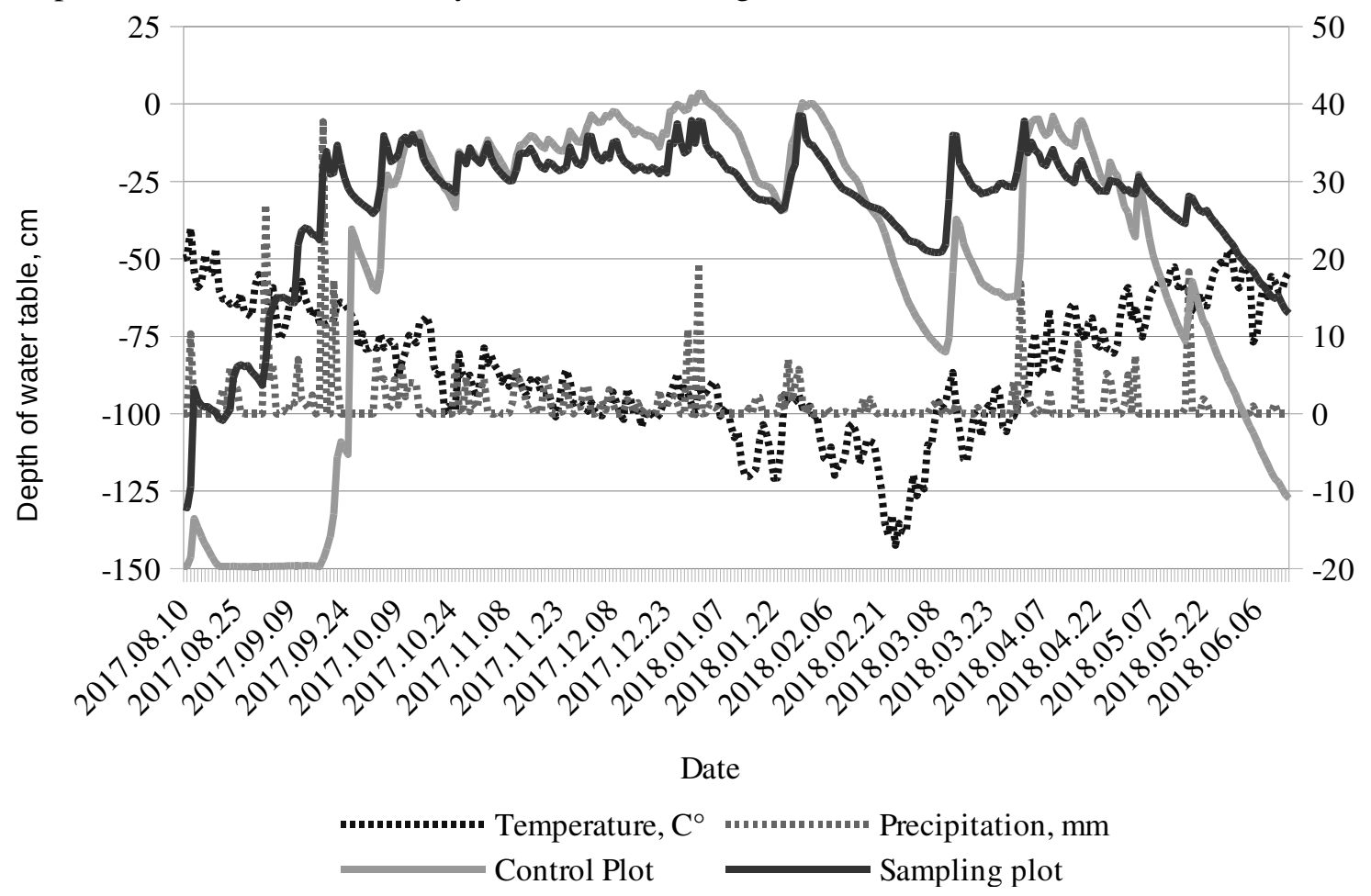

Fig. 5. Changes in water table 
It can be seen that from the very beginning the water table in the monitoring wells installed in the sampling plot is rising faster than in the wells in the control area. Since mid-September 2017, the water table has been close to the top of the soil both in the sampling plot and in the control area, and similar fluctuations in water levels can be observed until the beginning of March. There is a tendency for the water table in wells installed in the control areas to decrease more rapidly than in the sampling plots, and it can be attributed to compacted soil in sampling plots, higher share of water filled pores [14] and reduction of porosity due to compaction [5]. Other study objects show similar results in terms of disturbed groundwater flow in the sampling plots, but freezing and thawing seem to improve the hydraulic permeability in the compacted soil layer.

Water filtration properties are determined for the soil samples taken from the ditch banks and adjacent forest stands. Soil samples were collected in the summer of 2018. Data were analyzed to determine the ratio of the water filtration rate between the ditch bank and the adjacent forest stand (Table 1). Only the results of the second study object (C2K - control plot and $\mathrm{C} 2 \mathrm{P}$ - sampling plot) show that the water filtration rate in the sampling plot is relatively worse than in the control area. In other sites the situation is the opposite. The relatively high and low water filtration characteristics in the obtained results indicate that there is a large dispersion of data and that too few soil samples may have been analyzed for in-depth conclusions.

Table 1

Water filtration ratio $(\%)$ between forest stand and adjacent ditch bank

\begin{tabular}{|c|c|c|c|c|c|c|}
\hline Depth, cm & C1K & C1P & C2K & C2P & C3K & C3P \\
\hline $0-10$ & 42 & 2 & 6864 & 374 & 9 & 217 \\
\hline $10-20$ & 23 & 3460 & 1333 & 97 & 39 & 156 \\
\hline $20-40$ & 65 & 139 & 70 & 0 & 12 & 98 \\
\hline $40-80$ & 255 & 521 & 21 & 52 & 16 & 13 \\
\hline
\end{tabular}

\section{Conclusions}

1. The effect of soil compaction is mostly observed in the depth of $20-60 \mathrm{~cm}$. In the upper layer soil compaction is not observed because soil at this depth is swollen to fill the ruts, while the deepest layers have not been subjected to such high pressure.

2. Groundwater level measurements have shown that ditch banks have an impact on the water table. In all the sampling plots compared to the control areas there are time periods with a faster rise and longer fall of water table.

3. In order to assess the restoration of water filtration properties of compacted soil, this type of study should be carried out over a longer period of time. Repeated measurements of soil penetration resistance and groundwater monitoring data would give an impression of relative changes in soil status in the context of sample plots and control areas.

\section{Acknowledgements}

The study is implemented within the scope of the memorandum between LSFRI Silava and Joint stock company "Latvia state forests" from 11.10.2011.

\section{References}

[1] Fründ H.C., Averdiek A. Soil aeration and soil water tension in skidding trails during three years after trafficking. Forest Ecology and Management, 380, 2016, pp. 224-231.

[2] Wei L., Hulin F., Chevalier R., Archaux F., Gosselin F. Is plant diversity on tractor trails more influenced by disturbance than by soil characteristics? Forest Ecology and Management, 379(379), 2016, pp. 173-184.

[3] Van-Camp L., Bujarrabal B., Gentile A.R., Jones R.J.A., Montanerella, L., Olazabal, C., Selvaradjou, S.-K. Establishment under the thematic strategy for soil protection. 2004.

[4] Frey B., Kremer J., Rüdt A., Sciacca S., Matthies D., Lüscher P. Compaction of forest soils with heavy logging machinery affects soil bacterial community structure. European Journal of Soil Biology, 45(4), 2009, pp. 312-320. 
[5] Kozlowski T.T. Responses of Woody Plants To Human-Induced Environmental Stresses: Issues, Problems, and Strategies for Alleviating Stress. Critical Reviews in Plant Sciences, 19(2), 2000, pp. 91-170.

[6] Cambi M., Certini G., Neri F., Marchi E. The impact of heavy traffic on forest soils: A review. Forest Ecology and Management, 338, 2015, pp. 124-138.

[7] von Wilpert K., Schäffer J. Ecological effects of soil compaction and initial recovery dynamics: a preliminary study. European Journal of Forest Research, 125(2), 2006, pp. 129-138.

[8] Gebauer R., Martinková M. Effects of pressure on the root systems of Norway spruce plants (Picea abies[L.] Karst.). Journal of Forest Science, 51(No. 6), 2012, pp. 268-275.

[9] Maynard D.G., Senyk J.P. Soil disturbance and five-year tree growth in a montane alternative silvicultural systems (MASS) trial. 2004. [online][16.02.2019] Available at: https://cfs.nrcan.gc.ca/publications?id $=25004$

[10] Heninger R., Scott W., Dobkowski A., Miller R., Anderson H., Duke S. Soil disturbance and 10year growth response of coast Douglas-fir on nontilled and tilled skid trails in the Oregon Cascades. Canadian Journal of Forest Research, 32(2), 2002, pp. 233-246.

[11]Ebrecht L., Schmidt W. Nitrogen mineralization and vegetation along skidding tracks. Annals of Forest Science, 60(7), 2003, pp. 733-740.

[12] Laine J., Vasander H., Laiho R. Long-Term Effects of Water Level Drawdown on the Vegetation of Drained Pine Mires in Southern Finland. The Journal of Applied Ecology, 32(4), 1995, pp. 785.

[13]Zālītis P. Mežs un ūdens. Salaspils: LVMI Silava. 2012.

[14] Hamza M.A., Anderson W.K. Soil compaction in cropping systems: A review of the nature, causes and possible solutions. Soil and Tillage Research, 82(2), 2005, pp. 121-145.

[15] Olson N.C., Gulliver J.S., Nieber J.L., Kayhanian M. Remediation to improve infiltration into compact soils. Journal of Environmental Management, 117, 2013, pp. 85-95.

[16] Meirons Z. Kvartāra nogulumi. M.:1:200 000. Valsts geoloǵijas dienests. 2002. 